\title{
A Japanese Girl with Familial Hypocalciuric Hypercalcemia Discovered with Skin Nodules of Calcium Deposition: A Case Report
}

\author{
Yoshitsugu Yahashi, Takashi Sakurai and Soichi Kodama \\ Department of Pediatrics, Himeji Red Cross Hospital, Hyogo, Japan
}

\begin{abstract}
A case of Familial hypocalciuric hypercalcemia ( $\mathrm{FHH}$ ) whose proband was a child and discovered with skin nodules of calcium deposition was reported. The proband was a 4-year and 8month old Japanese girl in November 1996. A high serum thyroid-stimulating hormone (TSH) level was pointed out in a neonatal mass screening program. She was diagnosed as having congenital hypothyroidism due to an iodine transport defect, and thyroid hormone replacement therapy was started. At 1 year and 1 month old, skin nodules were noticed and diagnosed as metastatic calcinosis cutis on skin biopsy. Skin nodules in her mother were also pointed out. In view of the high serum calcium level, low urinary calcium excretion and normal serum parathyroid hormone (PTH) level, both of them were diagnosed as having $\mathrm{FHH}$.
\end{abstract}

Key words: familial hypocalciuric hypercalcemia, child, skin nodules, calcium deposition

\section{Introduction}

Familial hypocalciuric hypercalcemia (FHH) is usually characterized by a high serum calcium level, relatively low urinary calcium excretion (ratio of calcium clearance to creatinine clearance $[\mathrm{CCa} / \mathrm{Ccr}]<0.01$ ), and an inappropriately normal serum parathyroid hormone (PTH) level. This disorder is inherited in an autosomal dominant manner and shows almost complete penetrance. Despite life-long hypercalcemia, the affected individuals are usually asymptomatic and do not exhibit kidney stones, renal parenchymal dam-

Received: December 26, 1996

Accepted: December 3, 1997

Correspondence: Dr. Soichi Kodama, Department of Pediatrics, Himeji Red Cross Hospital, 5-30-1, Tatsunomachi, Himeji-shi, Hyogo 670-0032, Japan age, or skeletal complication (1-3). Most of probands were therefore discovered with an accidental serum calcium measurement after growning up. Although a number of FHH cases have been reported, no FHH case whose proband is a child discovered with skin nodules of calcium deposition has been reported. The present study deals with a very rare case of $\mathrm{FHH}$.

\section{Case Report}

The proband was a 4-year and 8-month old Japanese girl in November 1996. A high serum thyroid-stimulating hormone (TSH) level was pointed out in a neonatal mass screening program and then the girl was admitted to the department of pediatrics of Himeji Red Cross Hospital at 44 days old. A high serum TSH level, low serum free thyroxine level and high serum 
thyroglobulin level were revealed. A normal sized and sited thyroid gland was observed on both ultrasonography and computed tomography (CT) scan, but the thyroid gland was not detected on Tc-99m scintigraphy.In view of these results, she was diagnosed as having congenital hypothyroidism due to iodine transport defect (4) and thyroid hormone replacement therapy was started. At 1 year and 1 month old, a lot of skin nodules on the abdomen and both thighs were noticed and diagnosed as metastatic calcinosis cutis with skin biopsy. Skin nodules on both hands in her mother were also pointed out. The parathyroid function of the proband and her mother was examined. Table 1 shows the laboratory data for them. A high serum calcium level of $11.3 \mathrm{mg} / \mathrm{dl}$, a low urinary ratio of calcium to creatinine $(\mathrm{Ca} /$ $\mathrm{Cr}$ ) of 0.015-0.054, and a normal serum C-terminal parathyroid hormone (PTH) level of $0.5 \mathrm{ng} /$ $\mathrm{ml}$ (normal range: $\leq 0.5 \mathrm{ng} / \mathrm{ml}$ ) were recognized in the proband. A high serum calcium level of

Table 1 Laboratory data on parathyroid function

\begin{tabular}{lccc}
\hline & & Proband & Mother \\
\hline Serum Ca & $(\mathrm{mg} / \mathrm{dl})$ & 11.3 & 10.5 \\
Serum P & $(\mathrm{mg} / \mathrm{dl})$ & 6.0 & 3.8 \\
C-terminal PTH & $(\mathrm{ng} / \mathrm{ml})$ & 0.5 & 0.3 \\
Urinary Ca/Cr & $0.054 ; 0.015$ & $0.003 ; 0.059$ \\
\hline
\end{tabular}

$10.5 \mathrm{mg} / \mathrm{dl}$, low urinary ratio of $\mathrm{Ca} / \mathrm{Cr}$ of 0.03 0.059 , and normal serum C-terminal PTH level of $0.3 \mathrm{ng} / \mathrm{ml}$ were recognized in her mother. A brain $\mathrm{CT}$ scan revealed no calcium deposition and renal ultrasonography revealed no kidney stone in the proband. These results coincided with the laboratory data for FHH. As shown in Table 2, the serum calcium level gradually normalized and has been maintained within the normal range since the proband was 2 years and 6 months old. A high serum C-terminal PTH level of $0.9-1.0 \mathrm{ng} / \mathrm{ml}$ and a high serum intact PTH level of $240-290 \mathrm{pg} / \mathrm{ml}$ (normal range: $15-$ $30 \mathrm{pg} / \mathrm{ml}$ ) have been maintained since the proband was 4 years and 1 month old, and a low urinary ratio of $\mathrm{Ca} / \mathrm{Cr}$ of $0.038-0.085$ and extremely low ratio of calcium clearance to creatinine clearance $(\mathrm{CCa} / \mathrm{Ccr})$ of 0.001-0.003 have been maintained. Also, as shown in Table 2, thyroid function has been controlled to normal with thyroid hormone replacement therapy.

\section{Discussion}

FHH is usually characterized by life-long hypercalcemia and a paradoxically normal PTH level. In this case, the serum calcium level decreased to the normal range from $11.3 \mathrm{mg} / \mathrm{dl}$ but serum PTH inversely increased to three or four times the normal value. McMurtry et al. (5)

Table 2 Course of laboratory data

\begin{tabular}{llcrrrrrrrc}
\hline & & $44 \mathrm{~d}$ & $1 \mathrm{y} 3 \mathrm{~m}$ & $1 \mathrm{y} 6 \mathrm{~m}$ & $1 \mathrm{y} 11 \mathrm{~m}$ & $2 \mathrm{y} 6 \mathrm{~m}$ & $3 \mathrm{y} 5 \mathrm{~m}$ & $4 \mathrm{y} 1 \mathrm{~m}$ & $4 \mathrm{y} 3 \mathrm{~m}$ & $4 \mathrm{y} 6 \mathrm{~m}$ \\
\hline Serum Ca & $(\mathrm{mg} / \mathrm{dl})$ & 10.1 & 11.3 & 10.7 & 10.5 & 9.4 & 8.7 & 9.1 & 9.0 & 9.7 \\
Serum P & $(\mathrm{mg} / \mathrm{dl})$ & & 6.0 & 5.8 & 6.6 & 5.3 & 6.4 & 6.1 & 6.7 & 6.4 \\
C-terminal PTH & $(\mathrm{ng} / \mathrm{ml})$ & & 0.5 & & 0.4 & 0.5 & & 1.0 & 0.9 & 1.0 \\
intact PTH & $(\mathrm{pg} / \mathrm{ml})$ & & & & & & & 290 & 240 & 260 \\
Urinary Ca/ Cr & & & 0.054 & & & & & 0.038 & 0.085 & 0.069 \\
Cca/ Ccr & & & & & & & & 0.001 & 0.003 & 0.002 \\
\%TRP & & & & & & & & & 95.5 & 94.4 \\
TSH & $(\mu \mathrm{U} / \mathrm{ml})$ & 41.1 & 3.6 & 4.3 & 3.1 & 5.9 & 6.1 & & 5.7 & 8.5 \\
Free-T3 & $(\mathrm{pg} / \mathrm{ml})$ & 3.0 & 5.3 & & & & 3.1 & & 3.6 & 3.0 \\
Free-T4 & $(\mathrm{ng} / \mathrm{dl})$ & 0.89 & 1.70 & 1.45 & 1.38 & 1.66 & 1.15 & & 1.18 & 1.07 \\
\hline
\end{tabular}


surveyed a large kindred of FHH composed of 46 members spanning 5 generations ranging from a 1.5 to a 91 -year-old and reported the effect of age on serum PTH levels and serum calcium levels. They reported that serum PTH levels were within the normal range but rapidly increased with age in both children and young adults and serum PTH levels had risen to above the normal range by approximately age 30 . They also reported that serum calcium levels showed a statistically significant decline with age. But, in this report, there was no case in which the serum calcium level decreased to the normal range and the serum PTH level increased to above the normal range in childhood such as in our patient. Furthermore, there was no other report which deals with the course of the serum calcium level and serum PTH level in an FHH patient.

The gene defect in FHH is thought to disturb the ability of the parathyroid gland and kidneys to recognize or respond to changes in the extracellular $\mathrm{Ca}^{2+}$ concentration (1, 2, 6-8). Recently Brown et al. isolated a complementary DNA encoding an extracellular $\mathrm{Ca}^{2+}$-sensing receptor from bovine parathyroid (9), Pollak et al. described three mutations in the receptor gene in FHH and neonatal severe hyperparathyroidism (NSHPT) individuals (10). One of the mutations was identified in an FHH/NSHPT family and an NSHPT member was homozygous for the mutation, whereas FHH members were heterozygous. On the other hand, Aida et al. (11) identified another mutation of $\mathrm{Ca}^{2+}$-sensing receptor gene from an FHH family, but the proband, who was homozygous for the mutation, had a high serum calcium level with no symptom, whereas her parents, who were heterozygous, had a borderline serum calcium level. In other reports, NSHPT occurred in some families in which only one parent had clinical characteristics of FHH (12-16) or even in which both parents were normocalcemic $(17,18)$. These results suggest that there is a spectrum of phenotypes in FHH and NSHPT, and that our case is one phe- notype of $\mathrm{FHH}$.

Ours may be the first case of FHH complicated with congenital hypothyroidism due to iodine transport defect. The authors were not able to clarify the genetical relationship between FHH and congenital hypothyroidism due to an iodine transport defect.

\section{References}

1. Foley TP, Harrison HC, Arnaud CD, Harrison HE. Familial benign hypercalcemia. J Pediatr 1972; 81: 1060-7.

2. Marx SJ, Attie MF, Levine MA, Spiegel AM, Downs Jr RW, Lasker RD. The hypocalciuric or benign variant of familial hypercalcemia: clinical and biochemical features in fifteen kindreds. Medicine 1981; 60: 397-412.

3. Law WM, Heath III H. Familial benign hypercalcemia (hypocalciuric hypercalcemia): clinical and pathogenetic studies in 21 families. Ann Intern Med 1985; 102: 511-9.

4. Yoshimura R, Kodama S, Nakamura H. Classification of congenital hypothyroidism based on scintigraphy, ultrasonography and the serum thyrogloburin level. Kobe J Med Sci 1995; 41: 71-82.

5. McMurtry CT, Schranck FW, Walkenhorst DA, Murphy WA, Kocher DB, Teitelbaum SL, et al. Significant developmental elevation in serum parathyroid hormone levels in a large kindred with familial benign (hypocalciuric) hypercalcemia. Am J Med 1992; 93: 247-58.

6. Cooper L, Wertheimer J, Levey R, Brown E, Leboff $\mathrm{M}$, Wilkinson $\mathrm{R}$, et al. Severe primary hyperparathyroidism in a neonate with two hypercalcemic parents: management with parathyroidectomy and heterotopic autotransplantation. Pediatrics 1986; 78: 263-8.

7. Attie MF, Gill Jr JR, Stock JL, Spiegel AM, Downs $\mathrm{Jr}$ RW. Urinary calcium excretion in familial hypocalciuric hypercalcemia: persistence of relative hypocalciuria after induction of hypoparathyroidism. J Clin Invest.1983; 72: 667-76.

8. Khosla S, Ebeling PR, Firek AF, Burritt MM, Kao $\mathrm{PC}$, Heath III H. Calcium infusion suggests a "setpoint" abnormality of parathyroid gland function in familial benign hypercalcemia and more com- 
plex disturbances in primary hyperparathyroidism. J Clin Endocrinol Metab 1993; 76: 715-20.

9. Brown EM, Gamba G, Riccardi D, Lombardi M, Butters $\mathrm{R}$, Kifor $\mathrm{O}$, et al. Cloning and characterization of an extracellular $\mathrm{Ca}^{2+}$-sensing receptor from bovine parathyroid. Nature 1993; 366: 57580.

10. Pollak MR, Brown EM, Chou Y-HW, Hebert SC, Marx SJ, Steinmann B, et al. Mutations in the human $\mathrm{Ca}^{2+}$-sensing receptor gene cause familial hypocalciuric hypercalcemia and neonatal severe hyperparathyroidism. Cell 1993; 75: 1297303.

11. Aida K, Koishi S, Inoue M, Nakazato M, Tawata M, Onaya T. Familial hypocalciuric hypercalcemia associated with mutation in the human $\mathrm{Ca}^{2+}$ -sensing receptor gene. J Clin Endocrinol Metab 1995; 80: 2594-8.

12. Marx SJ, Attie MF, Spiegel AM, Levine MA, Lasker RD, Fox M. An association between neonatal severe primary hyperparathyroidism and familial hypocalciuric hypercalcemia in three kin- dreds. N Engl J Med 1982; 306: 257-64.

13. Eftekhari F, Yousefzadeh DK. Primary infantile hyperparathyroidism: clinical, laboratory, and radiographic features in 21 cases. Skel Radiol 1982; 8: 201-8.

14. Page LA, Haddow JE. Self-limited neonatal hyperparathyroidism in familial hypocalciuric hypercalcemia. J Pediatr 1987; 111: 261-4.

15. Lillquist $\mathrm{K}$, Illum $\mathrm{N}$, Jacobsen BB, Lockwood $\mathrm{K}$. Primary hyperparathyroidism in infancy associated with familial hypocalciuric hypercalcemia. Acta Paediatr Scand 1983; 72: 625-9.

16. Matsuo M, Okita K, Takemine H, Fujita T. Neonatal primary hyperparathyroidism in familial hypocalciuric hypercalcemia. Am J Dis Child 1982; 136: 728-31.

17. Ross III AJ, Cooper A, Attie MF, Bishop HC. Primary hyperparathyroidism in infancy. J Pediatr Surg 1986; 21: 493-9.

18. Harris SS, D'Ercole AJ. Neonatal hyperparathyroidism: the natural course in the absense of surgical intervention. Pediatrics 1989; 83: 53-6. 